\title{
On the synthetic way to novel peri-annelated imidazo[1,5]benzodiazepinones as the potent non-nucleoside reverse transcriptase inhibitors
}

\author{
Benedikta D. Puodziunaite*, Dr. Regina Janciene, Lidija Kosychova, and Zita \\ Stumbreviciute \\ Institute of Biochemistry, Mokslininku 12, \\ LT-2600 Vilnius, Lithuania \\ E-mail: apalaima@bchi.lt
}

(received 22 Apr 00; accepted 21 Sep 00; published on the web 29 Sep 00)

\begin{abstract}
A series of novel imidazo[1,5]benzodiazepines were synthesized.

Keywords: Imida[1,5]benzodiazepines, 9-nitro-1,5-benzodiazepines lithim aluminium hydride reductions
\end{abstract}

\section{Introduction}

It is widely accepted that the primary etiological agent for the acquired immunodeficiency syndrome is the human immunodeficiency virus type 1 (HIV-1). ${ }^{1}$ The anti-HIV chemotherapy era has started a decade ago. In the search for more effective and safe chemotherapeutic agents there has been considerable interest in non-nucleoside reverse transcriptase inhibitors or NNRTI's. ${ }^{2-4}$ It was found that a number of compounds representing various structural types inhibit HIV-1 reverse transcriptase (RTase). ${ }^{5-7}$ 
The derivatives of the TIBO (4,5,6,7-tetrahydro-5-methylimidazo [4,5,1$\mathrm{j}, k][1,4]$ benzodiazepin-2(1H)-one) series of NNRTI's were among the first to be discovered. ${ }^{8-11}$ These compounds act by a mechanism distinct from that of nucleoside analogs such as AZT, DDC or DDI. Some of the highly active compounds which inhibit the replication of HIV-1, e.g. R82150, were confirmed in vitro to be relatively nontoxic. Several analogs of the parent TIBO (R81250) halogenated in the aromatic ring have been studied and demonstrated anti-HIV activity at low concentrations. ${ }^{12,13}$ According to these findings, we initiated a preparation and testing of similar structures based on a 1,5-benzodiazepine skeleton (isoTIBO) isomeric to TIBO.

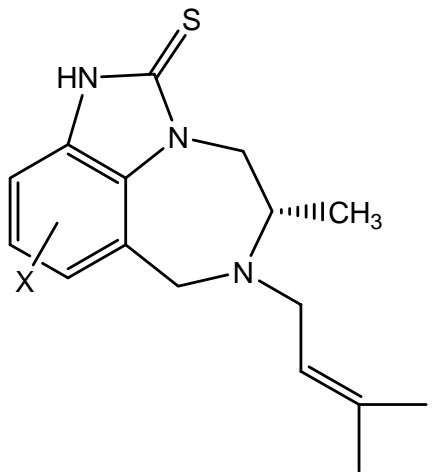

TIBO analogs

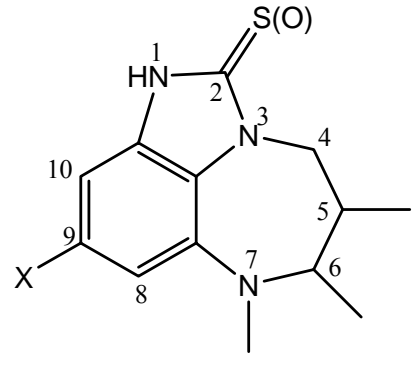

isoTIBO

\section{Strategy}

The synthons suitable for the construction of a tricyclic imidazo[1,5]benzodiazepine system incorporating the imidazole nucleus condensed both to the seven-membered heterocyclic and aromatic rings appeared to be molecules carrying the 9-nitrodihydro(or tetrahydro)-1,5benzodiazepinone $(\mathrm{A}, \mathrm{B})$ fragments. 
<smiles>O=C1CC=Nc2cccc([N+](=O)[O-])c2N1</smiles>

A

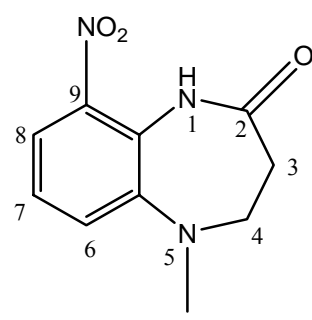

B

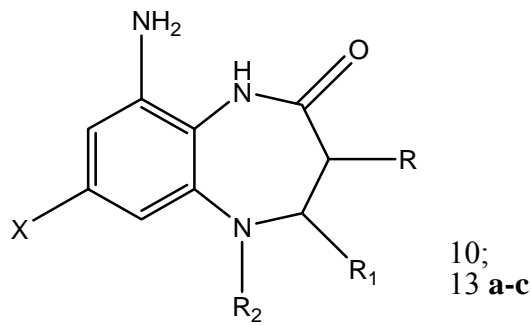

Triamines

The subsequent extension of the bicyclic 1,5-benzodiazepines to the desired tricyclic heterosystem can be achieved according to the previously ${ }^{13}$ described "capping" procedure ${ }^{10}$, including the reaction of the corresponding intermediate triamines with C-electrophilic reagents. The realization of this strategy requires 9-nitro substituted 1,5-benzodiazepinones. In this context, some synthetic routes for the preparation of these compounds were employed. Aromatic ring substituents could be incorporated prior to the synthesis of a desired heterocycle (A), and when this was not convenient or feasible the desired targets could be realized via direct electrophilic aromatic substitution in the tetrahydrobenzodiazepinone system (B).

Synthesis of tetrahydroimidazo[1,5,4-e,f][1,5]benzodiazepine-2(1H)-thiones(or ones). This paper reports the synthesis of tricyclic 1,5-benzodiazepine derivatives $\mathbf{1 ,} 2$ and $\mathbf{3}-\mathbf{-} \mathbf{8}$ incorporating a bromo substituent at C-9. Dihydrobenzodiazepinone 9 has been obtained in moderate yield by the condensation reaction of commercially available 3-nitro-1,2-phenylenediamine with ethyl acetoacetate. $^{14}$

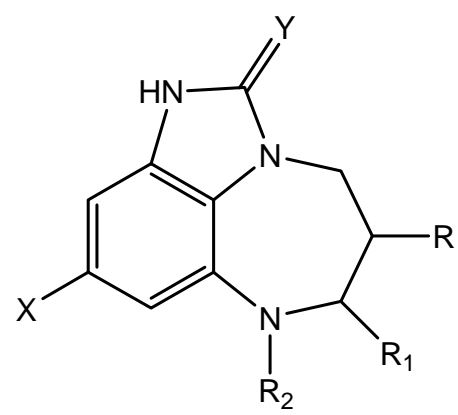

$$
\begin{aligned}
& 1 \mathrm{R}=\mathrm{R}_{2}=\mathrm{H}, \mathrm{R}_{1}=\mathrm{Me}, \mathrm{X}=\mathrm{H}, \mathrm{Y}=\mathrm{S} \\
& 2 \mathrm{R}=\mathrm{R}_{2}=\mathrm{H}, \mathrm{R}_{1}=\mathrm{Me}, \mathrm{X}=\mathrm{H}, \mathrm{Y}=\mathrm{O} \\
& 3 \mathrm{R}=\mathrm{R}_{1}=\mathrm{H}, \mathrm{R}_{2}=\mathrm{Et}, \mathrm{X}=\mathrm{Br}, \mathrm{Y}=\mathrm{S} \\
& 4 \mathrm{R}=\mathrm{Me}, \mathrm{R}_{1}=\mathrm{H}, \mathrm{R}_{2}=\mathrm{Et}, \mathrm{X}=\mathrm{Br}, \mathrm{Y}=\mathrm{S} \\
& 5 \mathrm{R}=\mathrm{H}, \mathrm{R}_{1}=\mathrm{Me}, \mathrm{R}_{2}=\mathrm{Et}, \mathrm{X}=\mathrm{Br}, \mathrm{Y}=\mathrm{S} \\
& 6 \mathrm{R}=\mathrm{R}_{1}=\mathrm{H}, \mathrm{R}_{2}=\mathrm{Et}, \mathrm{X}=\mathrm{Br}, \mathrm{Y}=\mathrm{O} \\
& 7 \mathrm{R}=\mathrm{Me}, \mathrm{R}_{1}=\mathrm{H}, \mathrm{R}_{2}=\mathrm{Et}, \mathrm{X}=\mathrm{Br}, \mathrm{Y}=\mathrm{O} \\
& 8 \mathrm{R}=\mathrm{H}, \mathrm{R}_{1}=\mathrm{Me}, \mathrm{R}_{2}=\mathrm{Et}, \mathrm{X}=\mathrm{Br}, \mathrm{Y}=\mathrm{O}
\end{aligned}
$$

Treatment of compound 9 with an eight-equivalent excess of LiAlH4 led to the reduction of the amide group, the $\mathrm{N}=\mathrm{C}$ bond and the nitro group to afford the air-sensitive triamine 10, which without isolation, was utilized in the cyclizations for the synthesis of $\mathbf{1}$ and $\mathbf{2}$ (Scheme 1). Conversion of $\mathbf{1 0}$ to thione $\mathbf{1}$ was accomplished with CS2 in an overall yield of $31 \%$ from $\mathbf{9} .^{13}$ 
Carbonylation of $\mathbf{1 0}$ was carried out with $1.1 \mathrm{~mol}$ equivalent of trichloromethyl chloroformate (diphosgene) in the presence of NMM. ${ }^{10}$ Subsequently, a hydrolytic workup of the carbamoyl chloride derivative formed in the course of this reaction was used to regenerate product 2 . This procedure led to the 2 in an overall $11 \%$ yield.

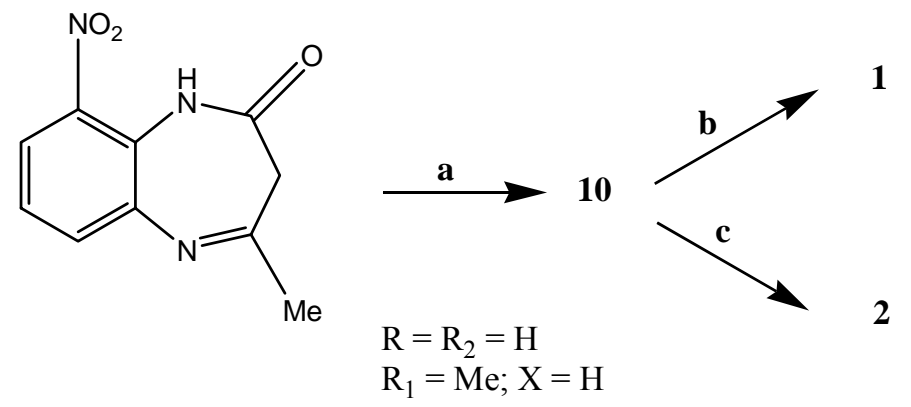

(a) $\mathrm{LiAlH}_{4}, \mathrm{TFH}$, reflux, $6 \mathrm{~h}$, then procedure (b) $\mathrm{CS}_{2}, \mathrm{EtOH}, \mathrm{rt}, 2 \mathrm{~h}$ or procedure (c) $\mathrm{ClCOOCCl}_{3}$ NMM, $\mathrm{CH}_{2} \mathrm{Cl}_{2},-10^{\circ} \mathrm{C}, 2 \mathrm{~h}$, rt, diocane $-\mathrm{H}_{2} \mathrm{O}$ (1:4.6), reflux, 45 min.

\section{Scheme 1}

The synthetic approach to the efficient synthesis of 9-bromo substituted title compounds lead to the expectation of substitutent effects for electrophilic substitution of the aromatic ring of tetrahydrobenzodiazepinones. 5-Acetyl-7-bromobenzodiazepinones 11a-t c which have been previously prepared ${ }^{15}$ were chosen as the substrates (Scheme 2). The aromatic C-7 bromo substituent in 11 acts as a convenient block for C-9 selective nitration in the next step. The para>ortho directing activating effect of the heterocyclic acylamino group is readily rationalized in the formation of 9-nitro compounds. Nitration of $\mathbf{1 1 a}-\left(\mathbf{c}\right.$ in $\mathrm{KNO} 3 / \mathrm{H} 2 \mathrm{SO} 4$ mixture at $-20{ }^{\circ} \mathrm{C}$ gave nitrobenzodiazepinones 12a- $\mathbf{c}$ in $52-63 \%$ yields. Precursors 12a-/c were then treated with $\mathrm{LiAlH} 4$ to reduce both nitro and amide (cyclic and noncyclic) functions in one pot. 


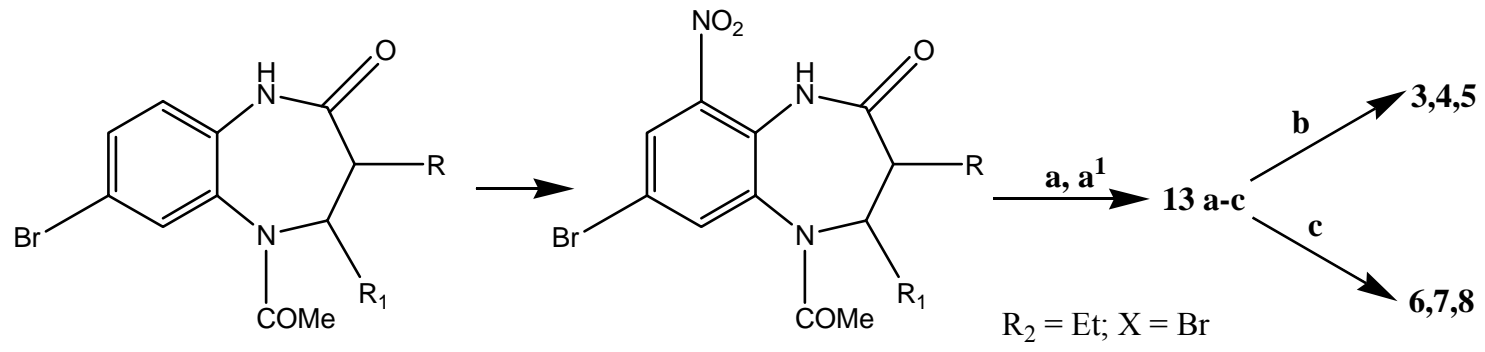

11 a-c

\begin{tabular}{ccc} 
& $\mathbf{R}$ & $\mathbf{R}_{\mathbf{1}}$ \\
\hline $\mathbf{a}$ & $\mathbf{H}$ & $\mathbf{H}$ \\
$\mathbf{b}$ & $\mathbf{M e}$ & $\mathbf{H}$ \\
c & $\mathbf{H}$ & $\mathbf{M e}$
\end{tabular}

12 a-c

(a) $\mathrm{LiAlH}_{4}$, TFH, 2h, rt, reflux 30 min, then procedure (b) $\mathrm{CS}_{2}, \mathrm{MeOH}, 15 \mathrm{~h}, \mathrm{rt}$; (a $\left.\mathrm{a}^{1}\right) \mathrm{H}_{2}, 5 \% \mathrm{Pd} / \mathrm{C}$

$\mathrm{TFH}, \mathrm{rt}, 2 \mathrm{~h}$, then filtred and added $\mathrm{LiAlH}_{4}, 30 \mathrm{~min}$, rt, then procedure (c) $\mathrm{NMM}, \mathrm{ClCOOCCl}_{3}$

$-10^{\circ} \mathrm{C}, 2 \mathrm{~h} . \mathrm{rt}$.

\section{Scheme 2}

Application of this procedure gave the desired products 13a-k but was less effective than in the case of product 10. Monitoring the progress of the reactions with LiAlH4 by TLC showed that prolonged heating caused a complete loss of starting materials and formation of several byproducts. Intending to accumulate larger quantities of the substances, first of all the nitro group in compounds 12 was catalytically reduced. The resulting 9aminobenzodiazepinones were not isolated but successively used in the reactions with LiAlH4. The modification of our reduction methodology also afforded triamines 13a-lc. These crude products similarly, as described above, were subjected to "capping" with CS2 or diphosgene to effect cyclization. So, we were able to complete the synthesis of 9 bromo substituted tricyclic derivatives $3-\mathbf{4}$ and $\mathbf{6}-\mathbf{-} \mathbf{8}$.

\section{Biological Screening-Results}

Some of compounds 1, 3-.5 have been selected by National Cancer Institute (NCI) and evaluated in the preliminary screen of the In Vitro Anti-AIDS Drug Discovery Program for their suppression of HIV-induced cytopathogenicity. This procedure involves the killing of T-4 lymphocytes in a CEM-SS cell line by HIV-1 and is designed to detect antiviral agents acting at any stage of the virus reproductive cycle. Structure-activity data are shown in Table 1 and represent values for 50\% effective concentration (EC50) against HIV cytopathic effects, 50\% 
inhibitory concentration (IC50) for cell growth and therapeutic Index (TI = IC50/EC50). All four compounds were relatively nontoxic to cells.

Table 1. Activity of selected imidazo[1,5]benzodiazepinethiones $1,3-5$

\begin{tabular}{cccc}
\hline Compound & IC50 (M) & EC50 (M) & $\begin{array}{c}\text { TI } \\
(\text { IC } / E C)\end{array}$ \\
\hline 1 (NSC 750834) & $1.18 \times 10-4$ & $4.40 \times 10-5$ & 4 \\
$3(\mathrm{NSC} 750831)$ & $1.33 \times 10-4$ & $1.67 \times 10-5$ & 29 \\
$4(\mathrm{NSC} 750832)$ & $1.38 \times 10-4$ & $5.18 \times 10-6$ & 30 \\
5 (NSC 750833) & $1.12 \times 10-4$ & $3.86 \times 10-6$ & \\
\hline
\end{tabular}

Among the compounds tested, two 9-bromo derivatives 4, 5 were confirmed to be active while compounds 1 and $\mathbf{3}$ to have moderate anti-HIV activity. The compounds $\mathbf{4 , 5}$ are less potent than the 8 (or 9)-halogen TIBO analogs ${ }^{13}$, however, these compounds inhibit viral replication in the same submicromolar range as "isoTIBO" derivative, which has a prenyl side chain at the N-7 position. ${ }^{16}$ The resulting therapeutic index (TI) for compounds $\mathbf{4 , 5}$ is not sufficient for further in vivo testing. These findings indicate that imidazo[1,5]benzodiazepinethiones share structural similarities with TIBO's, thus suggesting that the introduction of an unsaturated prenyl side chain is crucial for the higher anti-HIV activity.

Compounds 6-8 (NSC 711581, 711582, 711583) have been tested in the primary In Vitro Anti-tumor Screen of NCI. The cell panel consists of 60 lines against which the compounds were tested. None of the evaluated imidazo[1,5]benzodiazepinone derivatives exhibited anti-tumor activity.

\section{Experimental Section}

General Procedures. ${ }^{1} \mathrm{H}$ NMR spectra were taken on a Hitachi R-22 spectrometer operating at $90 \mathrm{MHz}\left(35^{\circ}\right)$. Chemical shifts $(\delta)$ are reported in ppm from TMS. IR spectra were obtained on a Specord 75 IR instrument. Mass spectra were recorded on a Hewlett Packard HP 5890 gas chromatography with a mass-selective detector HP 5971A (70eV). Ascending TLC was 
performed on Silufol UV254 silica gel plates. Column chromatography was performed with silica gel Chemapol L 40/100. Melting points were determined in open capillaries with a PTP apparatus and are uncorrected.

4,5,6,7-Tetrahydro-6-methylimidazo[1,5,4-e,f][1,5]benzodiazepine-2(1H)-thione (1). A suspension of LiAlH4 $(1.4 \mathrm{~g}, 36.8 \mathrm{mmol})$ in $50 \mathrm{~mL}$ of dry THF was brought to reflux and maintained for $2 \mathrm{~h}$. It was then cooled to $\mathrm{rt}$. To a stirred suspension a solution of dihydrobenzodiazepinone $9(1.0 \mathrm{~g}, 4.6 \mathrm{mmol})$ in $20 \mathrm{~mL}$ of THF was added dropwise over 20 min. The mixture was heated at reflux for $6 \mathrm{~h}$. It was then recooled with an ice bath and quenched with a careful sequential addition of $1.4 \mathrm{~mL}$ of $\mathrm{H} 2 \mathrm{O}$ in $4.2 \mathrm{~mL}$ of THF, $1.4 \mathrm{~mL}$ of $15 \%$ $\mathrm{NaOH}$ solution, and $4.2 \mathrm{~mL}$ of $\mathrm{H} 2 \mathrm{O}$. The mixture was warmed to $\mathrm{rt}$ and stirred for $0.5 \mathrm{~h}$ before the solid was filtered off. The filtrate was concentrated. The resultant dark oil was dissolved in $10 \mathrm{~mL}$ of dry EtOH and immediately used without further purification for synthesis of 1. Carbon disulfide $(1.8 \mathrm{~mL}, 30 \mathrm{mmol})$ was added and the solution was stirred under argon for $2 \mathrm{~h}$ at $\mathrm{rt}$. After cooling the formed precipitate was filtered. The crude solid was purified by recrystallization $(\mathrm{EtOH})$ to give $310 \mathrm{mg}(31 \%)$ of 1 as a white solid. 1: $\mathrm{mp} 242-244{ }^{\circ} \mathrm{C}$; IR (Nujol) 3380, 3107, $1623 \mathrm{~cm}^{-1}$; ${ }^{1} \mathrm{H}$ NMR (DMSO-d6) $\delta 1.25$ (d, 3H, $J=6.8 \mathrm{~Hz}, \mathrm{CH} 3$ ), 1.85-2.30 (m, 2H, CH2CH2N), 3.50-4.75 (m, 3H, CH, CH2N), 5.97 (s, 1H, NH), 6.37 (d, 1H, J $=8.0 \mathrm{~Hz}, \mathrm{H} 8), 6.47$ (d, 1H, J=7.9 Hz, H10), 6.86 (dd, 1H, H9), 12.44 (s, 1H, HNCS); ms, (m/z) $219\left(\mathrm{M}^{+}\right)$.

4,5,6,7-Tetrahydro-6-methylimidazo[1,5,4-e,f][1,5]benzodiazepin-2(1H)-one $\quad$ (2). To a solution of an intermediate triamine $(50 \mathrm{~mL}$ of dry $\mathrm{CH} 2 \mathrm{Cl} 2)$ obtained from the reaction of dihydrobenzodiazepinone $9(5.0 \mathrm{~g}, 22.8 \mathrm{mmol})$ and LiAlH4 $(7.0 \mathrm{~g}, 184 \mathrm{mmol})$ according to the procedure described above for the synthesis of $\mathbf{1}$, Nmethylmorpholine $(7.42 \mathrm{~mL}, 68.4 \mathrm{mmol})$ was added under argon. Then the mixture was cooled to $-10{ }^{\circ} \mathrm{C}$ and a solution of diphosgene (3.1 $\mathrm{mL}, 25.1 \mathrm{mmol}$ ) in $10 \mathrm{~mL}$ of $\mathrm{CH} 2 \mathrm{Cl} 2$ was added with stirring within $10 \mathrm{~min}$. The reaction mixture was allowed to stir for $30 \mathrm{~min}$ at $-10{ }^{\circ} \mathrm{C}$ and for $2 \mathrm{~h}$ at $\mathrm{rt}$. After standing overnight in refrigerator the formed white precipitate was filtered. The filtrate was concentrated to an oil. The residue was redissolved in dioxane/water $(30: 140 \mathrm{~mL})$ and the solution heated to reflux for 45 min. When cool, the solution was extracted with chloroform $(3 \times 40 \mathrm{~mL})$ and dried. Removal of the solvent afforded a brown residue. Column chromatography $(2: 1 \mathrm{CH} 2 \mathrm{Cl} 2$ :EtOAc) left a semisolid crude product that was triturated with $30 \mathrm{~mL}$ of Et2O to give, after filtration, $510 \mathrm{mg}(11 \%)$ of 2 as a pale grey solid. 2: mp $210-212{ }^{\circ} \mathrm{C}$; IR (Nujol) 3345, 3215, $1685 \mathrm{~cm}^{-1}$. ${ }^{1} \mathrm{H}$ NMR (DMSO-d6) $\delta 1.26(\mathrm{~d}, 3 \mathrm{H}, J=6.8 \mathrm{~Hz}, \mathrm{CH} 3), 1.85-2.30(\mathrm{~m}, 2 \mathrm{H}, \mathbf{C H} 2 \mathrm{CH}), 3.02-4.46(\mathrm{~m}, 3 \mathrm{H}$, CH, CH2N), 6.33 (d, 1H, $J=8.0 \mathrm{~Hz}, \mathrm{H} 8), 6.42$ (d, 1H, J=7.9 Hz, H10), 6.73 (dd, 1H, H9), 10.62 (s, 1H, HNCS); ms (m/z) $203\left(\mathrm{M}^{+}\right)$. 


\section{5-Acetyl-7-bromo-9-nitro-3-R-4-R ${ }^{1}$-2,3,4,5-terahydro-1H-1,5-benzodiazepin-2-ones} $(12 \mathrm{a}-(\mathrm{c})$. General procedure

A precooled to $-10{ }^{\circ} \mathrm{C}$ solution of KNO3 (2.42 g, 24 mmoles) in $25 \mathrm{~mL}$ of concentrated H2SO4 was added dropwise to a stirred solution of the bromobenzodiazepinone 11a- $\mathbf{c}$ (10 mmoles) in $35 \mathrm{~mL}$ of concentrated $\mathrm{H} 2 \mathrm{SO} 4$. The reaction mixture was left for approximately $16 \mathrm{~h}$ at $-20{ }^{\circ} \mathrm{C}$, stirred for $4 \mathrm{~h}$ at $\mathrm{rt}$, poured over ice and then extracted with EtOAc $(5 \times 40 \mathrm{~mL})$. The combined organic solutions were washed successively with saturated aqueous $\mathrm{Na} 2 \mathrm{CO} 3$ until neutral $\mathrm{pH}$, water and dried over Na2SO4. Solvent evaporation and recrystallization of the resulted brightyellow solid afforded product. Compound 12a $\left(\mathbf{R}=\mathbf{R}^{\mathbf{1}}=\mathbf{H}\right): 52 \%, \mathrm{mp} 170-172{ }^{\circ} \mathrm{C}$ (EtOAc/Et2O); ${ }^{1} \mathrm{H}$ NMR (CDCl3) $\delta 1.89$ (bs, 3H, CH3), 2.50-2.96 (m, 2H, CH2CO), 3.52 (m, $1 \mathrm{H}, \mathrm{CH} 2 \mathrm{~N}), 4.95(\mathrm{~m}, 1 \mathrm{H}, \mathrm{CH} 2 \mathrm{~N}), 7.72(\mathrm{~d}, 1 \mathrm{H}, J=2.2 \mathrm{~Hz}, \mathrm{H} 6), 8.34$ (d, 1H, J = 2.2 Hz, H8), 8.88 (bs, 1H, NH). Anal. Calcd for C11H10BrN3O4: C, 40.27; H, 3.07; Br, 24.35; N, 12.81. Found: C, 40.68; H, 3.08; Br, 23.85; N, 12.80. Compound 12b (R= Me, $\left.\mathbf{R}^{\mathbf{1}}=\mathbf{H}\right): 63 \%, \mathrm{mp}$ 187-190 ${ }^{\circ} \mathrm{C}(\mathrm{i}-\mathrm{PrOH}) ;{ }^{1} \mathrm{H}$ NMR $(\mathrm{CDCl} 3) \delta 1.16(\mathrm{~d}, 3 \mathrm{H}, J=6.8 \mathrm{~Hz}, \mathbf{C H} 3 \mathrm{CH}), 1.84$ (bs, 3H, CH3), 2.77 (m, 1H, CH), 3.54 (m, 1H, CH2), 4.60 (m, 1H, CH2), 7.72 (d, 1H, J = 2.2 Hz, H6), 8.30 (d, 1H, $J=2.2 \mathrm{~Hz}, \mathrm{H} 8), 8.79$ (bs, 1H, NH). Anal. Calcd for C12H12BrN3O4: C, 42.00; H, 3.53; Br, 23.29; N, 12.25. Found: C, 42.36; H, 3.58; Br, 23.60; N, 12.09. Compound 12c $(\mathbf{R}=$ H, $\left.\mathbf{R}^{1}=\mathbf{M e}\right): 62 \%, \mathrm{mp} 148-151{ }^{\circ} \mathrm{C}\left(\right.$ EtOAc); ${ }^{1} \mathrm{H}$ NMR $(\mathrm{CDCl} 3) \delta 1.19(\mathrm{~d}, 3 \mathrm{H}, J=6.8 \mathrm{~Hz}$, CH3CH), 1.74 (bs, 3H, CH3), 2.07-2.61 (m, 2H, CH2), 5.26 (m, 1H, CH), 7.63 (d, 1H, J= 2.2 $\mathrm{Hz}, \mathrm{H} 6), 8.32$ (d, 1H, J=2.2 Hz, H8), 8.85 (bs, 1H, NH). Anal. Calcd for C12H12BrN3O4: C, 42.00; H, 3.53; Br, 23.29; N, 12.25. Found: C, 42.47; H, 3.76; Br, 23.09; N, 12.44.

\section{4,5,6,7-Tetrahydro-9-bromo-7-ethyl-5-R-6-R ${ }^{1}$-imidazo[1,5,4-e,f][1,5]benzodiazepine-2(1H)- thiones (3-5). General procedure}

To a stirred suspension of LiAlH4 $(0.93 \mathrm{~g}, 24.5 \mathrm{mmol})$ in dry THF $(60 \mathrm{~mL})$ a solution of nitrobenzodiazepinone 12a-c ( $3 \mathrm{mmol})$ in $30 \mathrm{~mL}$ of THF was added. The mixture was stirred for $2 \mathrm{~h}$ at $\mathrm{rt}$ and then heated at reflux for $30 \mathrm{~min}$. It was then cooled to $10{ }^{\circ} \mathrm{C}$ and quenched with the sequential dropwise addition of $1 \mathrm{~mL}$ of $\mathrm{H} 2 \mathrm{O}, 3 \mathrm{~mL}$ of $15 \% \mathrm{NaOH}$ solution, and $1 \mathrm{~mL}$ of $\mathrm{H} 2 \mathrm{O}$. After $15 \mathrm{~min}$ the solid salts were removed by filtration. The filtrate was dried and concentrated to an oil. The thick brown residue was dissolved in $15 \mathrm{~mL}$ of dry $\mathrm{MeOH}$ and immediately combined with $\mathrm{CS} 2(0.4 \mathrm{~mL}, 6.7 \mathrm{mmol})$ in $5 \mathrm{~mL}$ of $\mathrm{MeOH}$ under nitrogen. The reaction mixture was stirred for $15 \mathrm{~h}$ at ambient temperature and then was kept for $2-3 \mathrm{~h}$ in icebox. The crude product was collected by filtration and purified by recrystallization. Compound $3\left(\mathbf{R}=\mathbf{R}^{\mathbf{1}}=\mathbf{H}\right)$ : 34\%, mp 247-250 ${ }^{\circ} \mathrm{C}$ (PrOH); IR (Nujol) 3145, 3105, $1610 \mathrm{~cm}^{-1}$; ${ }^{1} \mathrm{H}$ NMR (CDCl3/DMSO-d6, 1:2) $\delta 1.16(\mathrm{t}, 3 \mathrm{H}, J=6.9 \mathrm{~Hz}, \mathrm{CH} 3), 2.14(\mathrm{~m}, 2 \mathrm{H}, \mathbf{C H} 2 \mathrm{CH} 2 \mathrm{~N}), 3.22-3.57$ (m, 4H, two CH2N), 4.12 (bt, 2H, CH2NCS), 6.48 (d, 1H, J=1.9 Hz, H8), 6.67 (d, 1H, J=1.9 Hz, H10), 12.51 (bs, $1 \mathrm{H}, \mathrm{NH})$; $\mathrm{ms}(\mathrm{m} / \mathrm{z}) 311,313\left(\mathrm{M}^{+}\right)$. Compound $4\left(\mathbf{R}=\mathbf{M e}, \mathbf{R}^{\mathbf{1}}=\mathbf{H}\right): 31 \%, \mathrm{mp} 194-196{ }^{\circ} \mathrm{C}$ 
(MeOH/Et2O); IR (Nujol) 3145, 3105, $1610 \mathrm{~cm}^{-1} ;{ }^{1} \mathrm{H}$ NMR (CDCl3) $\delta 1.11$ (d, 3H, J=6.9 Hz, СН3CH), 1.20 (t, 3H, J = 7.0 Hz, CH3CH2), 2.35 (m, 1H, CH), 3.19-3.58 (m, 4H, two CH2N), $3.82(\mathrm{dd}, 1 \mathrm{H}, J=13.4$ and $8.2 \mathrm{~Hz}, \mathrm{CH} 2 \mathrm{NCS}), 4.44(\mathrm{dd}, 1 \mathrm{H}, J=13.4$ and $3.5 \mathrm{~Hz}, \mathrm{CH} 2 \mathrm{NCS}), 6.55$ (d, 1H, $J=1.8 \mathrm{~Hz}, \mathrm{H} 8), 6.79$ (dd, 1H, $J=1.8 \mathrm{~Hz}, \mathrm{H} 10), 11.32$ (bs, 1H, NH); ms (m/z) 325, 327 $\left(\mathrm{M}^{+}\right)$. Compound $5\left(\mathbf{R}=\mathbf{H}, \mathbf{R}^{\mathbf{1}}=\mathbf{M e}\right): 31 \%, \mathrm{mp} 209-212{ }^{\circ} \mathrm{C}($ EtOAc); IR (Nujol) 3135, 3095, $1610 \mathrm{~cm}^{-1}$; ${ }^{1} \mathrm{H}$ NMR (DMSO-d6) $\delta 1.10(\mathrm{~d}, 3 \mathrm{H}, J=6.9 \mathrm{~Hz}, \mathbf{C H} 3 \mathrm{CH}), 1.15$ (t, 3H, $J=6.9 \mathrm{~Hz}$, CH3CH2), 2.03-2.40 (m, 2H, CH2CH2N), 3.10-4.55 (m, 5H, CH and two CH2N), 6.47 (d, 1H, $J=1.9 \mathrm{~Hz}, \mathrm{H} 8), 6.65$ (d, 1H, $J=1.9 \mathrm{~Hz}, \mathrm{H} 10), 12.65$ (bs, $1 \mathrm{H}, \mathrm{NH}) ; \mathrm{ms}(\mathrm{m} / \mathrm{z}) 325,327\left(\mathrm{M}^{+}\right)$.

\section{4,5,6,7-Tetrahydro-9-bromo-7-ethyl-5-R-6-R ${ }^{1}$-imidazo[1,5,4-e,f][1,5] benzodiazepin-2(1H)- ones (6-(8). General procedure}

In a hydrogenation apparatus, equipped with a magnetic stirrer, to a solution of nitrobenzodiazepinone 12a- $\mathbf{c}(3.2 \mathrm{mmol})$ in $50 \mathrm{~mL}$ of dry $\mathrm{THF}$ the catalyst $\mathrm{Pd} / \mathrm{C}(5 \%, 200 \mathrm{mg})$ was added and the mixture hydrogenated at $\mathrm{rt}$ until the reaction came to an end. The consumption was $215 \mathrm{~mL}$ ( 3 equiv.). Then the mixture was filtered through a glass filter. The filtrate was added dropwise to a stirred suspension of LiAlH4 $(0.97 \mathrm{~g}, 25.6 \mathrm{mmol})$ in $50 \mathrm{~mL}$ of dry THF under nitrogen. The mixture was heated at reflux for $30 \mathrm{~min}$ and quenched with the sequential addition of $1 \mathrm{~mL}$ of $\mathrm{H} 2 \mathrm{O}, 3 \mathrm{~mL}$ of $15 \% \mathrm{NaOH}$ solution, and $1 \mathrm{~mL}$ of $\mathrm{H} 2 \mathrm{O}$. The solid was removed, the filtrate concentrated and the resultant dark oil was dissolved in $40 \mathrm{~mL}$ of dry $\mathrm{CH} 2 \mathrm{Cl} 2$. To this solution $\mathrm{N}$-methylmorpholine $(1.1 \mathrm{~mL}, 10.1 \mathrm{mmol})$ was added under argon or nitrogen. Then the mixture was cooled to $-10{ }^{\circ} \mathrm{C}$ and a solution of diphosgene $(0.46 \mathrm{~mL}, 3.72$ $\mathrm{mmol})$ in $5 \mathrm{~mL}$ of dry $\mathrm{CH} 2 \mathrm{Cl} 2$ was added. The reaction mixture was allowed to stir for 30 min at $-10{ }^{\circ} \mathrm{C}$ and for $2 \mathrm{~h}$ at $\mathrm{rt}$. After standing overnight in refrigerator the formed precipitate was filtered. The filtrate was washed successively with saturated $\mathrm{Na} 2 \mathrm{CO} 3$ solution, water and dried. The solvent was removed in vacuo and the resulting solid residue was purified by recrystallization. Compound $6\left(\mathbf{R}=\mathbf{R}^{1}=\mathbf{H}\right): 25 \%, \mathrm{mp} 260-262{ }^{\circ} \mathrm{C}$ (i-PrOH); IR (Nujol) 3355 , 3285, $1685 \mathrm{~cm}^{-1}$; ${ }^{1} \mathrm{H}$ NMR (DMSO-d6) $\delta 1.12(\mathrm{t}, 3 \mathrm{H}, J=7.0 \mathrm{~Hz}, \mathrm{CH} 3), 2.01(\mathrm{~m}, 2 \mathrm{H}$, CH2CH2N), 3.23-3.58 (m, 4H, two CH2N), 3.69 (m, 2H, CH2NCS), 6.49 (d, 1H, J = $1.9 \mathrm{~Hz}$, H8), 6.54 (d, 1H, J = 1.9 Hz, H10), 10.87 (s, 1H, NH); ms (m/z) 295, $297\left(\mathrm{M}^{+}\right)$. Compound 7 (R $\left.=\mathbf{M e}, \mathbf{R}^{1}=\mathbf{H}\right): 26 \%, \mathrm{mp} 231-233{ }^{\circ} \mathrm{C}$ (i-PrOH); IR (Nujol) 3355, 3290, $1690 \mathrm{~cm}^{-1}$; ${ }^{1} \mathrm{H}$ NMR (DMSO-d6) $\delta 0.98(\mathrm{~d}, 3 \mathrm{H}, J=6.9 \mathrm{~Hz}, \mathbf{C H} 3 \mathrm{CH}), 1.13(\mathrm{t}, 3 \mathrm{H}, J=6.8 \mathrm{~Hz}, \mathbf{C H} 3 \mathrm{CH} 2), 2.16$ (m, $1 \mathrm{H}, \mathrm{CH}), 3.05-3.93(\mathrm{~m}, 6 \mathrm{H}$, three $\mathrm{CH} 2 \mathrm{~N}), 6.47(\mathrm{~d}, 1 \mathrm{H}, J=1.9 \mathrm{~Hz}, \mathrm{H} 8), 6.55(\mathrm{~d}, 1 \mathrm{H}, J=1.9 \mathrm{~Hz}$, H10), $10.86(\mathrm{~s}, 1 \mathrm{H}, \mathrm{NH})$; ms (m/z) 309, $311\left(\mathrm{M}^{+}\right)$. Compound 8 (R = H, $\left.\mathbf{R}^{\mathbf{1}}=\mathbf{M e}\right): 25 \%, \mathrm{mp}$ 192-194 ${ }^{\circ} \mathrm{C}$ (EtOAc); IR (Nujol) 3350, 3280, $1690 \mathrm{~cm}^{-1}$; ${ }^{1} \mathrm{H}$ NMR (DMSO-d6) $\delta 1.06$ (d, 3H, $J$ $=6.9 \mathrm{~Hz}, \mathbf{C H} 3 \mathrm{CH}), 1.13(\mathrm{t}, 3 \mathrm{H}, J=6.9 \mathrm{~Hz}, \mathbf{C H} 3 \mathrm{CH} 2), 1.85-2.23(\mathrm{~m}, 2 \mathrm{H}, \mathbf{C H} 2 \mathrm{CHN})$, 3.07-4.12 (m, 5H, CH and two CH2N), $6.41(\mathrm{~d}, 1 \mathrm{H}, J=1.9 \mathrm{~Hz}, \mathrm{H} 8), 6.54(\mathrm{~d}, 1 \mathrm{H}, J=1.9 \mathrm{~Hz}$, 
H10), $10.81(\mathrm{~s}, 1 \mathrm{H}, \mathrm{NH}) ; \mathrm{ms}(\mathrm{m} / \mathrm{z}) 309,311\left(\mathrm{M}^{+}\right)$

\section{Acknowledgments}

The authors thank the staff of the National Cancer Institute, Bethesda MD, USA, for the antiHIV and anti-tumor test reports. We are grateful to the Foundation of Lithuanian Science and Studies and the Lithuanian Innovation Centre for financial support.

\section{References}

1. De Clercq, E. J. Med. Chem. 1995, 38, 2491.

2. De Lucca, G.V.; Otto, M.J. Bioorg. Med. Chem. Lett. 1992, 2, 1639

3. Patel, U.R.; Proudfoot, J.R. J. Org. Chem. 1992, 57, 4023.

4. Proudfoot, J.R. Bioorg. Med. Chem. Lett. 1995, 5, 163.

5. Artico, M.; Silvestri, R.; Pagnozzi, E.; Stefancich, G.; Massa, S.; Loi, A.G.; Putzolu, M.; Corrias, S.; Spiga, M.G.; La Colla, P. Bioorg. Med. Chem. Lett. 1996, 4, 837.

6. Vig, R.; Mao, C.; Venkatachalam, T.K.; Tuel-Ahlgren, L.; Sudbeck, E.A.; Uckun, F.M. Bioorg. Med. Chem. Lett. 1998, 8, 1461.

7. Chimiri, A.; Grasso, S.; Monforte, A.M.; Monforte, P.; Rao, A; Zappala, M.; Bruno, G.; Nicolo, F; Scopelliti, R. IL Farmaco 1997, 52, 673.

8. Pauwels, R.; Andries, K.; Desmyter, J.; Schols, D.; Kukla, M.; Breslin, H.; Raeymaekers, A.; Van Gelder, J.; Woestenborghs, R.; Heykants, J.; Schellekens, K.; Janssen, M.A.; De Clercq, E.; Janssen, P. Nature 1990, 343, 470.

9. For a lead references to the synthesis and evaluation of TIBO compounds, see: Ho, W.; Kukla, M.J.; Breslin, H.J.; Ludovici, D.W.; Grous, P.P.; Diamond, C.J.; Miranda, M.; Rodgers, J.D.; Ho, C.Y.; De Clercq, E.; Pauwels, R.; Andries, K.; Janssen, M.A.C.; Janssen, P.A.J. J. Med. Chem. 1995, 38, 794.

10. Pfaendler, H.R.; Weisner, F. Heterocycles 1995, 40, 717.

11. Gardiner, J.M.; Loyns, C.R. Tetrahedron 1995, 51, 11515.

12. Parker, K.A.; Corbun, C.A. J. Org. Chem. 1991, 56, 4600.

13. Parker, K.A.; Corbun, C.A. J. Org. Chem. 1992, 57, 97.

14. Puodziunaite, B.; Kosychova, L.; Stumbreviciute, Z.; Janciene, R.; Talaikyte, Z. J. Heterocyclic Chem. 1999, 36, 1013.

15. Puodziunaite, B. Synth. Commun. 1998, 28(24), 4537. 
16. Parker, K.A.; Dermatakis, A. J. Org. Chem. 1997, 62, 4164. 